\title{
The Impact of Revolutionary Spirits in Ibsen's An Enemy of the People
}

\author{
Md. Amir Hossain 1
}

Department of English, IBAIS University, Bangladesh

\begin{abstract}
This article attempts to focus on the limitation of societal relationship, individual freedom, helplessness of the bourgeois community, the pelf and power of the corruptive political party, the authoritarian policy of the compact majority, hypocrites and rottenness, the elasticity of individual affinity and kinship in the capitalist society, and everlasting conflict and contrast between truth and false. Here, I have also discussed rebellion, revolution and creation through applying critical comments of Camus as impacted in his famous book, The Rebel. It also bears the testimony of the revolutionary and protesting modes of Ibsen himself through resembling Doctor Stockmann of An Enemy of the People with a view to establishing a pollution and corruption free and fare society and community of his contemporary age. In this article, my purpose is to expose Stockmann as an embodiment of the $19^{\text {th }}$ century Scandinavian bourgeois society and community. It aims at dealing with Ibsen's hatred attitude towards contemporary bourgeois politics and politicians. It also deals with his fearlessness, adventurous determination and expedition against the then illegal political ruling system and anarchist tradition.
\end{abstract}

Keywords: Compact majority, Ibsen, Proletariat, Rebellion and Revolution, Revolutionary spirit and Stockann

\section{INTRODUCTION}

Henrik Ibsen (20 March 1828- 23 May 1906) was a major $19^{\text {th }}$ century Norwegian playwright of the realistic plays. Ibsen is often referred to as the "father of modern drama." He is called the greatest Norwegian author, celebrated as a national hero by Norwegians, and one of the most important playwrights for all time. Ibsen is regarded as one of the greatest teachers of the revolt of the modern spirit and inspiration. Ibsen has portrayed the character of protagonist, Doctor Stockmann in the play, An Enemy of the People with a view to focusing on his own revolutionary spirits. My paper deals with the petty bourgeois, snob, intellectual, where Ibsen recognizes a confession of faith as a great dramatic artist, remains alone in his stand as a revolutionary figure in the history of English literature. In this submission, I have purposefully discussed the rebellion, revolution and creation through applying critical judgments of Camus with a view to focusing on the revolutionary moods and spirits of Ibsen. His dramatic art, without his glorious rebellion against every authoritative institution, social and moral lies, and vestige of bondage is hardly conceived. His proud defiance, his enthusiastic daring, and his utterly indifference to consequence attempt at heralding a new dawn and the birth of a new generation. Actually, my purpose is to expose rebellion, revolution and creation, the revolutionary spirits of the playwright and his hatred attitudes towards his contemporary Norwegian bourgeois politics and politicians, Stockmann as an embodiment of the modern revolutionary spirits and the thinking groups of the proletariat.

\section{REBELLION AND REVOLUTION}

The revolution based on principles kills God in the person of His representative on earth. The revolution of the $20^{\text {th }}$ century kills what remains of God in the principles themselves and consecrates historical nihilism. The contemporary revolution that claims to deny every value is a standard for judging values. Man wants to reign supremely through revolution. The revolutionary is a rebel or he is not a revolutionary, but a man who turns against rebellion. If he is a rebel, he ends by taking sides against revolution. Every revolutionary ends by becoming either an oppressor or a heretic. Rebellion and revolution end in the same dilemma. Rebellion itself makes us the promise of such a value. Revolution supposes the absolute malleability of human nature and its possible reduction to the condition of a force. But rebellion is the refusal to be treated as an object. It is the affirmation of a nature common to all men, which eludes the world of power. Humiliated rebellion, by its contradictions, its sufferings, its continuous defeats, and its inexhaustible pride, must give its content of hope and suffering to nature. Metaphysical rebellion

${ }^{1}$ Corresponding Author: amir.hossain.16578@gmail.com 
tries to construct existence with appearances. Our revolution is an attempt to conquer a new existence, by action that recognizes no moral strictures. Man will be nothing to do, according to the revolution, if he fails to obtain from history, willingly or by force, unanimous approval. Rebellion's demand is unity; historical revolution's demand is totality. Revolution is always obliged to act in the hope, which is invariably disappointed of existence. Even unanimous consent does not suffice to create its existence. It is condemned to renounce, not only its own principles, but nihilism in order to rediscover the creative source of rebellion. A proverb says: "I rebel, therefore we exist" and "We are alone" of metaphysical rebellion, rebellion at grips adds that instead of killing and dying in order to produce the being that we are not, we have to live and let live in order to create what we are.

In The Rebel, Camus (1991) believes that revolt is one of the "essential dimensions" of mankind. It is useless to deny its reality - rather we must seek in it a principle of existence. But the nature of revolt changes radically in our times. It is no longer the revolt of the slave against the master, nor even the revolt of the poor against the rich. His main object is to draw a clear distinction between rebellion and revolution. His ideas come close to anarchism, for he recognizes that revolution always implies the establishment of a new system, whereas rebellion is action without planned issue.

Camus also points out that all revolutions in modern times have led to a reinforcement of the power of the State. The strange and terrifying growth of the modern State can be considered as the logical conclusion of inordinate technical and philosophical ambitions, foreign to the true spirit of rebellion, but which gives a birth to the revolutionary spirit of modern time. Rebellion signifies unlimited slavery. To escape slavery, the revolutionary mind, if it wants to remain alive, must return to the sources of rebellion and draw its inspiration from the only system of thought which is faithful to its origins.

Restraint is not the contrary of revolt. Revolt carries with it the very idea of restraint, and moderation, the birth of rebellion, can live by rebellion. It is a perpetual conflict, continually created and mastered by the intelligence. Whatever we may do, excess will always keep its place in the heart of man, in the place where solitude is found. We all carry within us our places of exile, our crimes and our ravages. But our task is not to unleash them on the world; it is to fight with them in ourselves and in others. Rebellion is still today at the basis of the struggle.

\section{Creation and Revolution}

In art, rebellion is consummated and perpetuated in the act of real creation, not in criticism or commentary. Revolution can only affirm itself in a civilization and not in terror or tyranny. The revolution and art of the $20^{\text {th }}$ century are tributaries of the same nihilism and live in the same contradiction. The contemporary revolution believes that it inaugurates a new world when it is the contradictory climax of the old one. Capitalist society and revolutionary society are one and the same thing to the extent that they submit themselves to the same meansindustrial production - and to the same promise. Art and society, creation and revolution must rediscover the source of rebellion where refusal and acceptance, the unique and the universal balance each other in a condition of acute tension. Rebellion itself is not an element of civilization. Rebellion alone, in the blind alley in which we live, allows us to hope for the future dreams. Beauty does not make revolutions. But a day will come when revolutions will have the necessity of beauty. The procedure of beauty, which is to contest reality while endowing it with unity, is also the procedure of rebellion.

\section{THE REVOLUTIONARY SPIRITS OF IBSEN}

The teaching of revolutionary spirit does not exclude artistic talent and knowledge. The teaching must be clear and coherent; the teacher himself must be conversant with ideas and thoughts what he teaches; these must be part of his flesh and blood, they must not hinder and perplex him in his moments of creation; he must be an intellectual figure of his own potentiality and outstanding capability for which he can be able to foster the dormant qualities of a man; he must be an enlightened soul and torch-bearer of human knowledge only for which he can enable to make people conscious of their own society and community; in short, these ideas must not have a disruptive influence upon him. Otherwise, Ibsen is no longer master of his own ideas, nor can ideas themselves be clear and coherent.The intellectual or ideological content can have an injurious impact upon the work of art. It may be realized that it is the impotence of the artist who has not satisfactorily adjusted himself to them and who is not able to be a perfect or true poet of his own ideas and thoughts. Contrarily, the real reason for the artist's frailty lies not in the ideological content of his work but in his confusion or lack of ideas and imaginations.

The teaching of protesting spirit lends interest of loftiness to Ibsen's work. However, while he teaches "revolt," he himself does not know to what end it should lead, but happens in such way that he values revolt for his own sake. If 
a man teaches revolt simply because it is revolt, not knowing himself to what end it should lead, and then, his teaching reflects a nebulous character. Like an artist, he thinks in terms of images, forms, and vagueness of his thinking being embedded in vague artistic images. An abstract and schematic element creeps into his creative work. And, it is a negative trait which is noticed in Ibsen's thought and ideas. George Brandes tells us of a certain "bombthrower" who, in defending himself in court, regards Ibsen as an advocate of anarchism. A small group of anarchists who are present listened to the trades of Stockmann against the compact majority and universal suffrage. And, it cannot be ignored that these trades bear a close resemblance to the principles espoused by the anarchists. Ibsen's own views bear the resemblance. Ibsen hates the state, and gladly, participates in a revolution that destroys the hateful institution. Ibsen who declares himself ready to take part in a revolution against the state unequivocally is not the least bit concerned with the form of social relationship. Concerning the modern spirit, in one of his letters to Brandes in 1872, he says that freedom of thought and spirit thrives best under absolution. Ibsen also says that the interests of freedom should be retained always; freedom follows those who oppose it to commit a sin against the modern spirit.

Ibsen realizes that the modern constitutional state is superior in many ways to the state ruled by the public control. Ibsen reveals his essential indifference to politics. Ibsen, the enemy of the state, the tireless preacher of the revolt of the modern spirit reconciles himself to be the most tyrannical form of government. The reader does not see that the "revolt" which Ibsen preaches is just as meaningless as Brand's moral law. In the play, An Enemy of the People, Ibsen has created such a protagonist through whom we can observe the influence of the modern revolutionary spirits of his state.

\section{STOCKMANn AS An EMbodiment OF MODERn REVOLUTIONARY SPIRIT}

Now this submission attempts at applying the revolt of the modern spirit in Ibsen's An Enemy of the People through portraying Stockmann. He gets himself entangled in a whole series of the most absurd and helpless contradiction. At the mass meeting, he says that the democratic press lies shamelessly when it tells the masses that they are the "real essence" of the people: "The masses are nothing but raw material which may, some day, be refined into individuals!" (Act IV, 195). Here, Stockmann also presents his most irrefutable scientific arguments as follows:

Look at the enormous difference there is between a breed of animal that's cultivated and one that is uncultivated! Just look at a common farmyard hen. What is such a stunted piece of rubbish worth as flesh? Not much! And, what kind of eggs of does it lay? Any common rook or cow can lay eggs just as good. But take a cultivated a Spanish or Japanese hen, or take a fine pheasant or turkey, and see the difference! Consider dogs, with which we human beings have so much in common! Think first of a simple mongrel! —one of those filthy, ragged common curs that lope along the streets and defile the walls of our houses. And, then put that mongrel next to a greyhound with a distinguished pedigree whose ancestors have been fed delicate meals for generations and have had the opportunity to listen to a harmonious voices and music. Don't you think the brain of that greyhound is differently developed from that of the mongrel? You bet your life it is! It's the pups of these cultivated animals that trainers teach to perform the most amazing tricks (Act IV, 195-196).

From the above quotation, we would not go into the question of how far a Japanese hen, a poodle, or any other kind of domesticated animal can be compared to the best of the animal kingdom. The scientific arguments of Stockmann imply only those individuals belonging to the better elements, and having "descended through many generations from an aristocratic stock, have lived on delicate food, and harmonious music."At the risk of being impertinent, he descends from such people. As far as his own life is concerned, it is a life of a proletarian intellectual. A proletarian intellectual, who is socially conscious, ought not to attribute his mental development to his ancestry but to realize that he himself is responsible for having acquired his education and ideas during the course of a lifetime crowded with work. Stockmann fights with the compact majority because the "majority" refuses to accede to the complete reconstruction of the municipal bath, which he thinks to be necessary for the welfare of the sick. It is very easy for Stockmann to observe that majority is on the side of the sick that flocks to the town from far and wide, while those who object to overhauling the baths are actually in the minority. If he perceives the condition, he will realize how foolish it is to rail against the "majority" who actually constitutes the compact majority with whom our hero faces complexities and difficulties. Firstly, there are the shareholders of the municipal baths; secondly, the landlords, thirdly, the newspapermen and publishers, and lastly, the townspeople - who are under the influence of these elements and follow them blindly. In proportion to the first groups, the townspeople naturally form the compact majority. If Stockmann bothers to observe this situation, he will discover that the majority against whom he thunders to the great glee of anarchists are not really enemies of progress rather it is their ignorance and backwardness, which are products of their dependence on a financially powerful minority. If he realizes this, he will no doubt forfeit the 
applause of the anarchists, but he will win the truth - the truth which he loves because of his scientific backwardness which he fails to comprehend why the anarchists applaud Stockmann: his very manner of thinking reveals the same confusion that characterizes them. He thinks in the most abstract terms, such as good and evil. He does not realize that truth is not absolute but may belong to various categories through depending on its origin.

The exploiting minority cannot avoid falsifying questions of social relationship, consciously or unconsciously. The exploited majority, on the other hand, hardly knows where the shoe pinches. Finally, the direct necessity forces the majority to stare truth in the face, whereas the minority sees only the warts and the wrinkle on the face of the truth. On the fundamental lie of the exploiting minority, there arises a vast and highly complicated structure based on more and more lies, which continues to blind them to the truth. It takes, therefore, the utter naiveté of Stockmann to expect that the minority loves the truth unselfishly. According to Stockmann, "But I'm thinking of the few, the individuals amongst us who have adopted the new, fresh, burgeoning truths as their watchword! These men stand at the outposts, so far forward that the compact majority hasn't yet arrived -and there they are fighting for those truths which are still too new to man's conscious mind to have any majority behind them"(Act IV, 193). Stockmann indignantly retorts to all this: "I intend to state a revolution against the lie that truth is a monopoly of the majority! What are these truths to which the majority clings?" (Act IV, 193). Individuals do not drop as the rain from heaven. They are flesh of the flesh and bone of the bone of that social class where they were born. They come forward as the ideologists of their particular class. Stockmann wanders into the realm of abstraction; and it never occurs to him where social questions are concerned one must seek the truth out a different manner than one does in matter of pure science. Stockmann, in his scientific studies of the masses, turns out to be a pure idealist. For instance, he imagines that he has discovered what the masses cannot think freely. While we hear his explanation, let us not forget for a moment that freedom of thought is to him practically synonymous with morality:

But luckily the idea that culture demoralizes is an old inherited fairy tale. No, it's stupidity, poverty and foul living conditions that do a Devil's work! In a house where the rooms aren't aired and the floors swept away my wife Catherine says, they ought to be scrubbed too, but there can be two opinions on that in such a house, I say, within two or three years people lose the capacity for moral thought and moral action. Lack of oxygen debilitates the conscience. And, there's a shortage of oxygen in many houses in this town, from the sound of things, if the whole of this damned majority can be so devoid of conscience is to want to build the prosperity of their town on a quagmire of deceit and lies (Act IV, 198).

When the shareholders of the municipal bath, together with the landlords, wish to deceive the public and the initiative in this deception is taken by the representative of the shareholders. It can be explained by poverty and "lack of oxygen" in their homes, which has enervated their conscience. When the politicians are corrupted and reactionary, it is because of the doors of the mansions are seldom swept when the proletarians rebel against hypocrisy and rottenness because they inhale so much oxygen, especially in times of unemployment, when they are thrown out on the streets. Stockmann reaches the limits of his endless confusion. Poverty is a source of corruption, and those who blame corruption on "culture" are profoundly mistaken. But, all corruptions are due to poverty that is an ennobling influence under all conditions. Contrarily, no matter how corruptive the influence of poverty may be, "lack of oxygen" does not prevent the proletarians of the modern age from being far more sensitive than any other class of society to everything which stands for progress, truth and nobility. The fact that a certain class is poor does not explain how poverty reacts on its development. "Lack of oxygen" always represents a minus quality in the algebraic sum of social development. However, this "lack" is due not to weakness on the part of the productive forces of society, but to the general social relationship between the forces of production, which leaves the producers in poverty while the appropriators indulge their every whim and extravagance; this "lack" is rooted in social system itself while blunting and demoralizing a certain section of population, it gives rise to revolutionary thoughts and feelings among the majority of the people by placing them in a negative position in relation to the existing order. This is precisely what we find in the capitalist society of Ibsen's contemporary age, where there is tremendous concentration of wealth while poverty is on the increasing majority, and the impoverishment of the masses come a revolutionary discontent and an increasing understanding of the road to emancipation.

But, Stockmann has not the faintest inkling. He is, absolutely, incapable of understanding that a proletarian might have the capacity of clear thought and action even though he breathes foul air and the floors of his home leave to be desired in the way of cleanness. This is why Stockmann, who regards himself as a thinker "at the outposts" of humanity, ridicules the idea: 
The doctrine that the plebs, the masses, the mobs, are the living heart of the people - that they are the people and that the common man, all those ignorant and incompetent millions, have the same right to sanction and condemn, to advise and govern, as the few individuals who are intellectually aristocrats (Act IV, 194-195).

This is the reason why Stockmann, one of the "intellectually distinguished few," raises an objection against democracy which Socrates commented long ago:

Who form the majority--in any country? The wise or the fools? I think, we'd all have to agree that the fools are in a terrifying, overwhelming majority, all over the world! But in the name of God, it can't be right that the fools should rule the wise! (Act IV, 92-193).

Against Stockmann words, a man presents at the meeting shouts: "That's talking like an enemy of the people!"(Act IV, 199) And the whole crowd screams: "Yes, yes, yes! He's an enemy of the people! He hates his country! He hates the people!'(Act IV, 199) And the excited voices: “Make him stand down!"(Act IV, 198). They are entirely convinced that Stockmann is an enemy of the people. From their point of view, they are perfectly right. We know, of course, that Stockmann is far from wishing the people harm in demanding the rebuilding of the baths. In this respect, he is an enemy of the exploiting minority rather than that of the people. But in his battle against the minority, he raises the very objections invented by those who fear the rule of the majority. Unintentionally, even unconsciously, he speaks as a true enemy of the people as a political reaction. Stockmann wants truth, not bloodshed. But the point is that he himself does not realize the significance of his words about the right to vote. In his astounding naiveté he fears that the people seek to solve questions regarding the general origin of knowledge, not problems of social practice, which are closely bound up with the interests of the masses, and are decided against these interests when the masses themselves do not have the right to pass upon them. Ibsen has created Stockmann with a view to unveiling his democratic moods and outlooks. He believes in democratic right and freedom of speech. The aim of his play writing is to democratize people's thoughts and freedom of speech of his contemporary age.

The spiritual aristocrats of bourgeois society consider themselves as chosen men, or Nietzsche regards it as Supermen. To these men, the masses, the "majority" of the people are inferiors. The Supermen are permitted for everything. It is only to them that the command: "To your own self be true!" This does not go for ordinary mortals. Wilhelm Hans has rightly observed that those who have no "mission" in life have only one mission left, "to sacrifice themselves." As to the contempt in which the masses are held by the spiritual aristocrats, we need no further example than Stockmann's remarkable speech still fresh in our memory. In his speech, he arrives at reactionary, absurd conclusions, which do not credit to Ibsen. However, we must not overlook a mitigating circumstance. In modern capitalist society, with its sharply defined class distinctions, the majority, consisting of the proletariat, represents the only class capable of being inspired with zeal for everything noble and progressive; in early bourgeois society, there is no such class. There are the sick and the poor. But the poorer classes of the population live under conditions which are hardly conducive to mental stimulation, but which rather lulls them to sleep by making them obedient tools of the compact majority.

Ibsen' opinions and ideas are being formulated, a working class, in the present sense of the term, has not yet developed in Norway, and is, therefore, nowhere evident in public life. Thus, it is very clear why Ibsen, in writing Stockmann's speech, fails to mention the Norwegian working class as a progressive social force. Ibsen sees people as they actually are typically in bourgeois countries: an utterly undeveloped mass sinks in mental torpor, differing from the "pillars of society," who lead them in their manners are cruder and their homes dirtier. Stockmann is mistaken in attributing the mental lethargy of the poorer sections of the bourgeois society to "lack of oxygen," but this erroneous explanation is causally related to the idealistic nature of his social views. When an idealist like Stockmann ponders over the development of social ideas, and attempts to remain on the scientific ground, he appeals to oxygen, to upsweep boors, to heredity in short, to the physiology and pathology of the individual organism; but it never occurs to him to consider the social relationship which in the last analysis focus on the psychology of every society. This is really understandable in bourgeois society, where there is a talk of supermen. These people are so isolated from the society around them, and their development precedes at suck a snail-like pace, that is impossible for them to perceive the causal relationship between the "course of ideas" and the "course of things" in human society. It must be remarked that this relationship is observed by scientists in the $19^{\text {th }}$ century. The class struggle as an important factor in the whole social movement is indicated by historian and publisher of the Restoration period. But the supermen of the stagnating bourgeois society have a pleasing discovery to make without 
them society would be devoid of thinkers. Therefore, they consider themselves supermen. Stokmann considers them"poodle-men." This reactionary absurdity which slips into his speech does not prove that Ibsen sympathizes with the political reaction. It must be said, to the honor of the great poet, that those readers in France and Germany who consider Ibsen to be a bearer of revolutionary ideas which confirm the rule of the privileged minority over the majority, are greatly mistaken. Ibsen is completely indifferent to politics, but, as he himself says that he hates politicians. His way of thinking is apolitical; fundamentally as it is his outstanding characteristics.

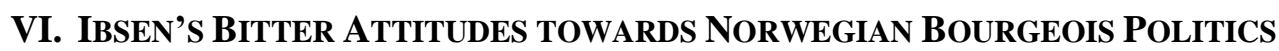

Ibsen himself aptly characterizes his attitude towards politics and politicians. They have to live upon the crumbs from the revolutionary table of the past century, and even fare has been masticated over and over again. These ideas of the past require new substance, new interpretation. Freedom, equality and fraternity are no longer the same things they were in the days of the guillotine of blessed memory. The politicians do not understand. The people demand only special revolution, revolutions in the outside world, in the sphere of politics. What is really indispensable is a revolution of the spirit of man.

Ibsen's distinction between political revolutions and other revolutions for those not content with superficial details is untenable. The French revolution to which Ibsen refers is both political and social. And, this must be said of every social movement which deserves to be considered as revolutionary spirits. Actually, the revolutionary speech signifies Ibsen's negative attitude towards politicians. He hates them because they re-chew the "crumbs" from the table of the great French revolution; he hates them because they do not go far enough, their vision does not penetrate beneath the surface of social life. It is the same charge which the social democrats of Western Europe storm against bourgeois politicians. The political representatives of the upper bourgeoisie of Western Europe no longer mention any kind of revolution. In so far as Ibsen makes charge against bourgeois politicians he is right, and his defiance measures the height of his ideals and the strength of his character. However, Ibsen imagines that all politicians are like those he knows in his bourgeois homeland at the time his views are being formed, and he is wrong; his hatred of politicians reflects the narrowness of his horizon. He forgets that the great heroes of the French Revolution were also politicians and that their heroic deeds were performed in the field of politics. The crux of the matter is "the revolution of the spirit of man" for the sake of revolution itself - enthusiasm for the formed independent of content. Ibsen's defiance of politicians under the aforementioned circumstances is a measure of his height of his revolutionary ideals.

Actually, Ibsen was a social reformer of his contemporary age. He was just as remote from socialism as from any other theory based upon social relationship. He described his reactions upon returning to his native country after staying twenty seven years in foreign country. He commended but also much to be deplored. He is disappointed to observe that the most indispensable individual rights are not being properly recognized. A ruling majority is arbitrarily curtailing freedom of speech and faith. There are still much to be done in that direction, but it is beyond the power of the present democracy to solve these problems. An element of nobility enters Norwegian political life-administration, representatives and press. Ibsen hastens to explain that he is not thinking of nobility of birth, wealth, or even intellect; he is thinking of nobility of character, will and mind for which he can get free mind. Nobility will come, according to Ibsen, from two sources: "from our women and from our working men."

In the first place, the ruling majority with whom Ibsen takes issue recalls the compact majority against whom Stockmann struggles and revolts. The group is accused of disregarding individual freedom in general and freedom of speech in particular. Unlike Stockmann, Ibsen does not say that "lack of oxygen" condemns the "masses" to stupidity. No working class is depicted as social group to which Ibsen looks for the reform of Norwegian society. Ibsen is not a conscious enemy of the working class. When he thinks it as a special section of the masses as he did at Trondheim, but he is no longer satisfied with "milking the goat" with the "revolution of the spirit of man" as an end in itself, but has arrived at a concrete political task, the broadening and empowering of personal rights. But, this task which must be considered as one of those "special revolutions" so bitterly condemned by Ibsen. But the playwright always feels uncomfortable in the field of politics; therefore, he hastens to return to the old stamping ground of ethics: he expects great things to result from the injection of a noble element into the political life of Norway. According to modern critics, Ibsen is the enemy of the state as well as the tireless preacher of "the revolt of the modern spirit" which reconciles himself to one of the tyrannical forms of the then Norwegian political system. Thus Ibsen has opposed the then system of bourgeois politics through portraying the character of Stockmann. 


\section{Thinking Group of The Proletariat}

Let it must be understood: there is a great deal of truth in what Ibsen focuses on the nobility of character, will and mind. His poetic sensibility cannot bear bourgeois moderation—which distorts the noblest sentiments when it points to the workers as the social group most capable of introducing into the political life of Norway and the element of nobility. The proletariat, pressing with all its power towards its final goal, shall indeed free its mind and purity its will. However, Ibsen misunderstands the true relationship of things. The moral rebirth of the proletariat can take place when it begins to strive towards its great goals; for no amount of preaching can lift it out of the bourgeois morass. The noble spirit of enthusiasm is brought to the working class. Ibsen's way of thinking remains apolitical in the widest sense of the word far from all social questions. He preaches the purification of the will, the revolution of the spirit of man, but he does not know what goal to set for the purified will, nor what social conditions the spirit of man ought to combat after its revolution. The thinking groups of proletariat sympathize with the revolution of the spirit of man as long as the revolution takes place and does not threaten the existing social order.

The "thinking group" of the proletariat fully realizes the inadequacies of Ibsen's manner of thinking and his artistic creations. It cannot help but love the Norwegian poet/dramatist as a man who deeply hates bourgeois opportunism, and as an artist who brilliantly clarifies the psychology of that opportunism. The revolution of the spirit of man, which finds an expression in the revolutionary strivings of the proletariat, is an expression of a revolution against bourgeois triviality against the weakness of the soul which Ibsen has combated and revolted resembling Stockmann in the play, An Enemy of the People. We still hear in the thundering voice of Stockmann: "I am now one of the strongest men in the whole world" (Act V, 222). At last, gathering his wife, Catherine, his daughter, Petra, and two sons round him, he whispers to them: " ... the strongest man in the world is he who stands most alone" (Act V, 222). Actually, it proves that Stockmann is always vigorous and adamant in his decision even in great dilemma. He is the self-creation of the playwright himself, through whom Ibsen's philosophy proves a perfect paradigm of the $19^{\text {th }}$ century Scandinavian revolutionary spirits and inspirations.

\section{CONCLUSION}

Finally, we see that Ibsen represents a paradoxical case of an artist who captivates the thinking groups of both of the two great irreconcilably opposed classes of his contemporary bourgeois society. Only a man who develops in a social atmosphere altogether dissimilar from the scene of the colossal class struggle of our modern times can be such an artist. In fact, this paper attempts to deal with rebellion, revolution and creation through applying critical comments of Camus, the modern revolutionary spirits of the playwright and his bitter attitudes towards the $19^{\text {th }}$ century Scandinavian bourgeois politics and politicians, Stockmann as a representative of the modern revolutionary spirits, and the thinking groups of the proletariat as well.

\section{REFERENCES}

[1] Bradbrook, M. C. (1946). Ibsen The Norwegian. London: Chatto \& Windus .94-95.

[2] Camus, Albert. (1956, 1991). The Rebel. Anthony Bower (Trans). Alfred A. Knopf, Inc. 246, 272

[3] Ferguson, Robert. (Trans.) (2006). Said About Ibsen-By Norwegian Writers, Oslo: Norwegian Ministry of Foreign Affairs NORLA and Gyldendal Norsk Forlog. 41-45.

[4] Goldman, Emma. (1914).The Social Significance of The Modern Drama, Boston: Richard G. Badger. 41-42.

[5] Gray, Ronald. (1977). Ibsen—a dissenting view. Cambridge: Cambridge University Press. 84- 98.

[6] Hussein, Salina. (Ed.) (2006). Ibsen-er-Natak- o-Kobita, Dhaka: Mawla Brothers. 249-272.

[7] Ibsen, Henrik. (1871).“To My Friend The Revolutionary Orator.” Northam, John (Trans.) in The Collected Poems of Henrik Ibsen.245-246. 8.___ (1960). An Enemy of the People.

[8] McFarlane, James Walter. (Trans. \& Ed.) Vol-V1.London: Oxford University Press.

[9] Plekhanov, G. V. (2005). "Ibsen, Petty Bourgeois Revolutionist”, Ed. Carl Rollyson. New Jersey: Salem Press Inc.https://www.marxists.org/archive/plekhanov/1908/xx/ibsen.htm

[10] Shaw, Bernard. (1913). The Quintessence of Ibsenism. New York: Hill and Wang. 94-97. 